\title{
New genus and species record of reef coral Micromussa amakusensis in the southern South China Sea
}

\author{
Chin Soon Lionel $\mathrm{Ng}^{1,2}$, Sudhanshi Sanjeev Jain ${ }^{1}$, Nhung Thi Hong Nguyen ${ }^{1}$, Shu Qin Sam², \\ Yuichi Preslie Kikuzawa ${ }^{2}$, Loke Ming Chou ${ }^{1,2}$ and Danwei Huang ${ }^{1,2^{*}}$ (D)
}

\begin{abstract}
Background: Recent taxonomic revisions of zooxanthellate scleractinian coral taxa have inevitably resulted in confusion regarding the geographic ranges of even the most well-studied species. For example, the recorded distribution ranges of Stylophora pistillata and Pocillopora damicornis, two of the most intensely researched experimental subjects, have been restricted dramatically due to confounding cryptic species. Micromussa is an Indo-Pacific genus that has been revised recently. The revision incorporated five new members and led to substantial range restriction of its type species and only initial member M. amakusensis to Japan and the Coral Triangle. Here, we report the presence of Micromussa amakusensis in Singapore using phylogenetic methods.
\end{abstract}

Results: A total of seven M. amakusensis colonies were recorded via SCUBA surveys at four coral reef sites south of mainland Singapore, including two artificial seawall sites. Colonies were found encrusting on dead coral skeletons or bare rocky substrate between 2 and $5 \mathrm{~m}$ in depth. Morphological examination and phylogenetic analyses support the identity of these colonies as $M$. amakusensis, but the phylogeny reconstruction also shows that they form relatively distinct branches with unexpected lineage diversity.

Conclusions: Our results and verified geographic records of $M$. amakusensis illustrate that, outside the type locality in Japan, the species can also be found widely in the South China Sea. Moreover, our discovery provides a new genus and species record in Singapore and represents the southern-most occurrence of the species in the Indo-Pacific. Despite the extensive survey efforts in Singapore over the last three decades, taxonomic studies integrating morphological and molecular methods remain instrumental in quantifying the actual coral species diversity.

Keywords: Coral reef, Integrative taxonomy, Phylogenetics, Scleractinia, Singapore

\section{Background}

Reef-building corals are amongst the most extensively studied animals in the marine environment. At the turn of the millennium, the diversity and distribution of zooxanthellate stony coral species (Cnidaria: Anthozoa: Scleractinia) had appeared to be precisely characterised and resolved (Veron 1995, 2000, 2002). Yet, phylogenetic analyses performed in the last two decades have shown the need for a plethora of taxonomic revisions (Fukami et al. 2004, 2008; Budd et al. 2010;

\footnotetext{
* Correspondence: huangdanwei@nus.edu.sg

${ }^{1}$ Department of Biological Sciences, National University of Singapore, Singapore 117558, Singapore

${ }^{2}$ Tropical Marine Science Institute, National University of Singapore, Singapore 119227, Singapore
}

Gittenberger et al. 2011; Benzoni et al. 2012, 2014; Arrigoni et al. 2016a; Kitahara et al. 2016). These changes are impacting our understanding of the distribution of even the most intensely researched species (Obura 2016).

Stylophora pistillata Esper, 1797 (Pocilloporidae), for instance, is considered a 'lab rat' for coral experimental studies (Keshavmurthy et al. 2013), owing to it being purportedly common and wide-ranging, both geographically and ecologically (Veron and Pichon 1976; Veron 2000). Comprehensive sampling throughout most of its range, from the Red Sea and Persian/Arabian Gulf to the western Pacific Ocean, has revealed that it comprises four distinct lineages, with two of them 
more closely related to Seriatopora hystrix Dana, 1846 than the remaining lineages of $S$. pistillata sensu lato (Keshavmurthy et al. 2013). The considerable genetic variation despite limited morphological distinction among these lineages (Stefani et al. 2011) means that biological and ecological inferences made at the species level have to be constrained within each of the four regions spanned by these lineages (Central Indo-Pacific, Chagos-Madagascar-South Africa, Gulf of Aden-Zanzibar-Madagascar, and Red Sea-Persian/ Arabian Gulf-Kenya).

Similarly, for Pocillopora Lamarck, 1816 (Pocilloporidae), detailed taxonomic work on the genus has revealed that many colonies previously identified as the widespread and common $P$. damicornis Linnaeus, 1758 , may actually be $P$. acuta Lamarck, 1816 (Schmidt-Roach et al. 2014). Also a well-studied 'lab rat' for experimental work in the Indo-Pacific (e.g. Ben-Haim et al. 2003; Cumbo et al. 2013; Poquita-Du et al. 2019a), many P. damicornis-like colonies have been confirmed to be $P$. acuta at multiple localities, including Japan (Kitano et al. 2015), Philippines (Torres and Ravago-Gotanco 2018), Singapore (Poquita-Du et al. 2017), American Sāmoa (Montgomery et al. 2019), Austral and Cook Islands (Mayfield et al. 2015), and Hawai'i (Johnston et al. 2018). These discoveries have wide-ranging impacts, even for the evaluation of species conservation status (see Agapow et al. 2004; Mace 2004; Ely et al. 2017). For example, a recent investigation of the identity of Pocillopora colonies in Singapore has shown that $P$. acuta is the only pocilloporid species remaining on its reefs following the historical loss of four species driven by habitat loss, coastal urbanisation and coral bleaching (Poquita-Du et al. 2019b). Due to the rapidly changing environment impacting corals locally and worldwide (Pandolfi et al. 2003; Hughes et al. 2014, 2017), the distribution of coral taxa ought to be assessed continually, particularly for those that have been revised taxonomically.

Micromussa Veron, 2000 (Lobophylliidae), is an IndoPacific genus with type species Acanthastrea amakusensis Veron, 1990, from Amakusa Island, Japan. Possessing gross morphological characteristics similar to the IndoPacific genus Acanthastrea Milne Edwards \& Haime, 1848 , it was initially recognised as a separate genus due to the smaller corallite diameter of $\leq 8 \mathrm{~mm}$ for its first members-M. minuta (Moll \& Best, 1984), M. amakusensis, and M. diminuta Veron, 2000 (Veron 2000). The genus was later said to be established 'to include species of Acanthastrea with corallites less than $5 \mathrm{~mm}$ diameter' (Veron 2002: 127). Based on more recent analyses integrating molecular and morphological data by Arrigoni et al. (2016a) and Huang et al. (2016), M. minuta was reverted to Acanthastrea minuta, M. diminuta moved to Goniopora, and three existing species transferred into Micromussa, namely A. lordhowensis Veron \& Pichon, 1982, Montastrea multipunctata Hodgson, 1985, and A. regularis Veron, 2000. Two new species, Micromussa indiana Benzoni \& Arrigoni, 2016 and M. pacifica Benzoni \& Arrigoni, 2016, were also described (Arrigoni et al. 2016a).

Following these extensive revisions, the type species of Micromussa and its only initial member M. amakusensis had its recorded range reduced to Japan and the Coral Triangle, while the genus remained widespread in the Indo-Pacific, ranging from the southern Red Sea to French Polynesia. Past records from the disjointed range in the southern Red Sea and western Indian Ocean (Veron 2000) have been attributed to the new species $M$. indiana (Arrigoni et al. 2016a).

In this study we reassess the distribution range of $M$. amakusensis based on records in the northern and eastern South China Sea, as well as introduce a new genus and species record in Singapore.

\section{Results \\ Field observations}

A total of seven colonies were observed via SCUBA surveys at four sites among the southern islands of Singapore. Two of the sites were fringing reefs at Kusu Island $\left(1^{\circ} 13^{\prime} 31.57^{\prime \prime} \mathrm{N}, 103^{\circ} 51^{\prime} 35.71^{\prime \prime} \mathrm{E}\right)$ and Sultan Shoal $\left(1^{\circ} 14^{\prime} 21.48^{\prime \prime} \mathrm{N}, 103^{\circ} 38^{\prime} 52.89^{\prime \prime} \mathrm{E}\right)$. The other two sites were on granite rock seawalls on the eastern $\left(1^{\circ} 13^{\prime}\right.$ $\left.42.71^{\prime \prime} \mathrm{N}, 103^{\circ} 51^{\prime} 18.90^{\prime \prime} \mathrm{E}\right)$ and western $\left(1^{\circ} 13^{\prime} 47.87^{\prime \prime} \mathrm{N}\right.$, $\left.103^{\circ} 50^{\prime} 55.65^{\prime \prime} \mathrm{E}\right)$ shores of Lazarus Island. Colonies, seen at depths of $2-5 \mathrm{~m}$ below chart datum, encrusted on dead coral skeletons or bare rocky substrate. The average size of the colonies at Kusu and Lazarus Islands was $19.7 \pm 4.3 \mathrm{~cm}$ (geometric mean diameter $\pm \mathrm{SD}, n=5$ ).

\section{Morphological identification}

Colonies of Micromussa amakusensis are encrusting, with a thick fleshy mantle, and are light brown to mottled red-yellow in colour. Both intra- and extracalicular budding modes are observed. Corallites are mostly ceroid with a variable diameter ranging from 7 to 15 $\mathrm{mm}$, and a relief of $3-6 \mathrm{~mm}$. Corallite shapes range considerably, with some corallites having regular outlines and others being more elongate. The few widelyspaced corallites are separated by a groove filled with sediment and algae when alive. Septa are in 3-4 cycles (24-36 septa), each with 3-5 large septal teeth, and granules are scattered on the septal face. Free septa are irregularly arranged. The columella, $1-3 \mathrm{~mm}$ in diameter, is spongy (Fig. 1).

Species similar to M. amakusensis include M. multipunctata, which is distinctly plocoid and has less variable, smaller corallites (up to $9 \mathrm{~mm}$ in diameter) (Hodgson 1985); and M. lordhowensis, which has larger 

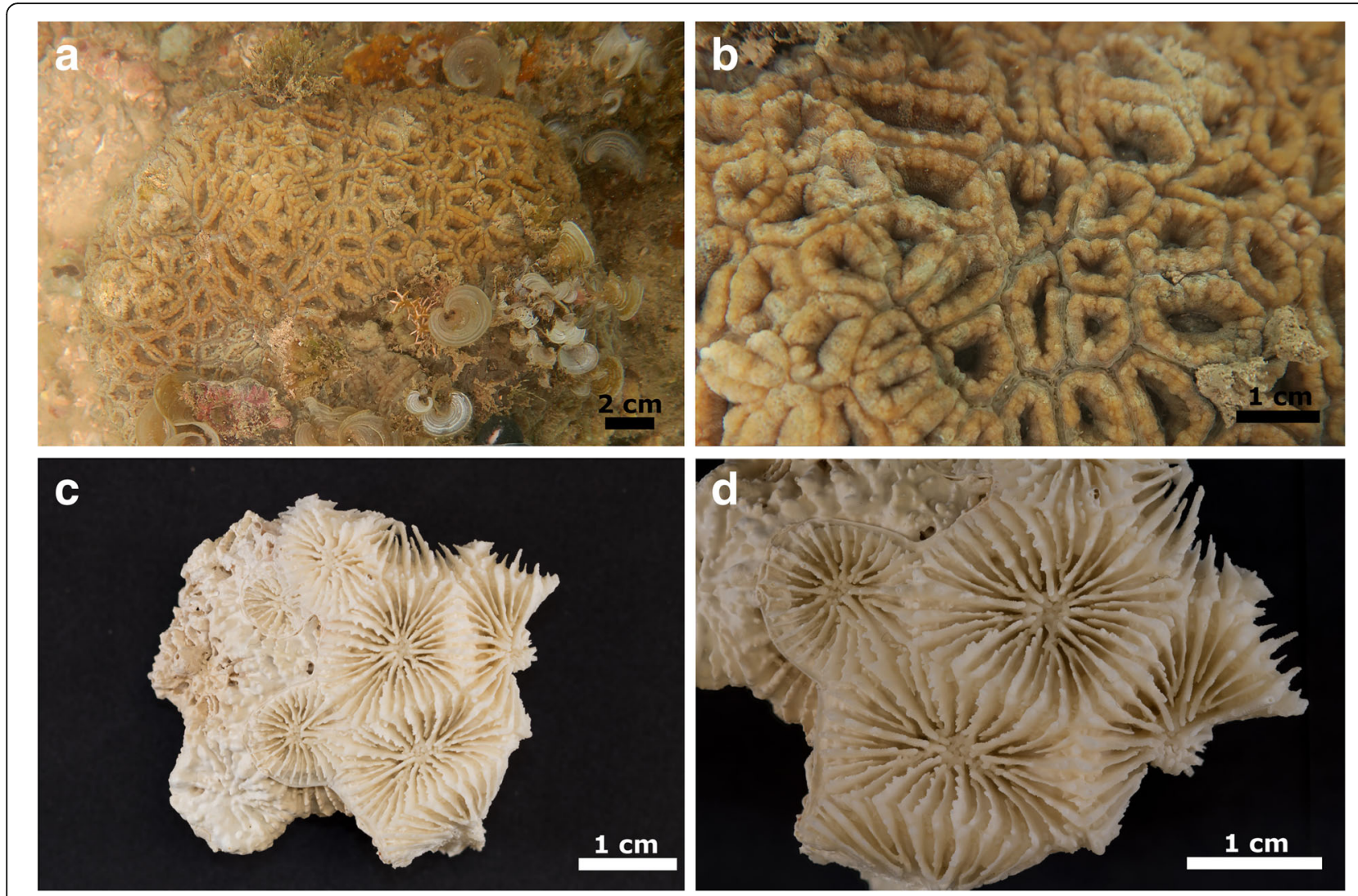

Fig. 1 Micromussa amakusensis (Veron 1990): a Colony in situ; b corallite in situ; c colony skeleton; d corallite skeleton

and more angular corallites (up to $20 \mathrm{~mm}$ in diameter) (Veron and Pichon 1980; Turak and DeVantier 2011; Arrigoni et al. 2016a).

\section{Phylogenetic analysis}

Our phylogeny reconstruction recovers the same genus clades as Arrigoni et al. (2016a) and Huang et al. (2016) (Fig. 2; see also Arrigoni et al. 2016b, 2019). In particular, Micromussa forms a sister clade to Homophyllia (bootstrap support or $\mathrm{BS}=71$, posterior probability or $\mathrm{PP}=1$ ), and both are a strong sister group to Australophyllia wilsoni $(\mathrm{BS}=100, \mathrm{PP}=1)$. The five Micromussa spp. included here form a well-supported clade (BS = $100, \mathrm{PP}=1)$. Both specimens from Singapore are in a clade comprising M. amakusensis and M. multipunctata with moderate support $(\mathrm{BS}=66, \mathrm{PP}=1)$. Interestingly, while $M$. multipunctata is a well-supported clade $(\mathrm{BS}=$ 93, $\mathrm{PP}=1)$, M. amakusensis sequences form a paraphyly. The distinct lineages represent previously unreported species-level diversity, but the limited sampling in terms of specimens (seven) and geography (Japan and Singapore) suggests that a more comprehensive collection is needed to characterise this species precisely.
Taken together, the morphological observations and phylogenetic analyses support the new genus and species record of M. amakusensis in Singapore.

\section{Discussion}

Micromussa amakusensis has been documented widely from the Indo-Pacific, but is poorly studied and considered globally rare (Arrigoni et al. 2016a; Veron et al. 2016). The species was first recorded in western Thailand, Tanegashima Island and mainland Japan (including Amakusa Island after which the species was named), and Vanuatu (Veron 1990). Its known distribution range was then expanded to include the Central IndoPacific, western Pacific, Gulf of Aden and the southern Red Sea (Veron 2000).

Two studies following the above range characterisation have led to increasing restriction of the range of $M$. amakusensis. First, a treatise of all scleractinian corals in Moreton Bay, eastern Australia, suggests that a species there recognised as $M$. amakusensis may be distinct from the holotype of Amakusa Island due to the more abundant septa (Wallace et al. 2009). Second, according to Veron (2000), records from the central Pacific appear to be doubtful, and furthermore, no examination of 


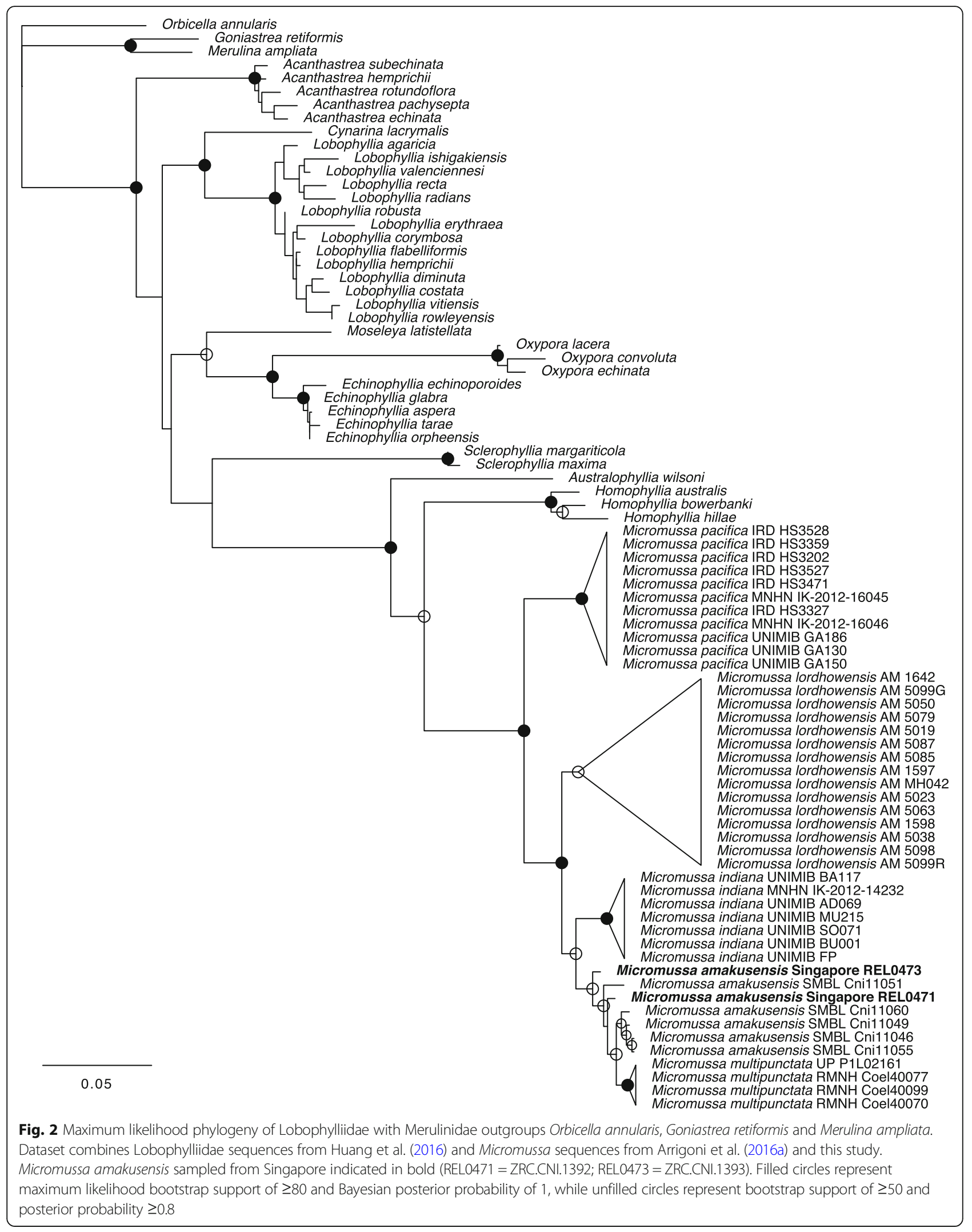


specimens have been reported. This casts doubt on the M. amakusensis records in central and western Pacific (Veron 2000), including one from Papua New Guinea (Turak and DeVantier 2007). The Red Sea and western Indian Ocean records have also been affirmed as $M$. indiana based on an integrative morpho-molecular analysis (Arrigoni et al. 2016a). Consequently, $M$. amakusensis' distribution range has been limited to Japan and the western part of the Coral Triangle sensu Hoeksema (2007) (see also Arrigoni et al. 2016a).

Our consolidated records of $M$. amakusensis from published literature show that the species is known to occur outside the type locality in Japan. In particular, published records are known in the northern and eastern South China Sea-in Vietnam (Vo et al. 2002), Hong Kong (Ang et al. 2003; Chan et al. 2005), Brunei (Turak and DeVantier 2011), and Calamian Islands, Philippines (Veron 2000) (Fig. 3). The new record of this species in Singapore suggests that there is evidence of its dispersal range along the coasts of South China Sea and Sunda Shelf.

In Singapore, the genus Micromussa and in particular M. amakusensis have not been documented from historical or contemporary records (Huang et al. 2009; Guest et al. 2016; Wong et al. 2018; Chow et al. 2019), so our discovery represents the southern-most record of this species in the South China Sea region (Huang et al. 2015). The present finding is remarkable given that species losses have occurred over the last five decades as a consequence of coastal urbanisation in Singapore (Hoeksema and Koh 2009; Poquita-Du et al. 2019b). Growth rates of encrusting lobophyllids have rarely been reported in the literature (Madin et al. 2016). Nevertheless, based on the approximate age of the seawalls at Lazarus Island that were constructed in the early 2000s, and a conservative growth estimate of $0.5-1 \mathrm{~cm}$ per year for encrusting or massive corals, we suggest that the colonies observed are at least 10-18 years old. Despite the chronic anthropogenic impacts and habitat degradation (Chou et al. 2019), it is evident that coral recruitment is active not only on Singapore's reefs, but also in non-reefal areas such as the seawalls of Lazarus Island on which $M$. amakusensis has been observed (see also Lee et al. 2009; Ng et al. 2012).

Micromussa amakusensis appears to be widespread in Singapore, spanning the western (Sultan Shoal) and eastern (Kusu Island) limits of the established reefs here. However, it has only been detected after more than three decades of coral reef monitoring (Guest et al. 2016). It is likely that some colonies were either misidentified as similar-looking, fleshy taxa such as Dipsastraea spp. or Acanthastrea spp., or that their encrusting growth form and drab colouration rendered them less noticeable by surveyors. Regardless, as in the case of Pocillopora acuta described above, $M$. amakusensis may be found in other areas of its newly-expanded range and, following our record, be recognised more readily in the future.

\section{Conclusions}

Through field observations, morphological identification based on skeleton morphology, molecular phylogenetics and species mapping, we have here better established the geographic range of Micromussa, with particular

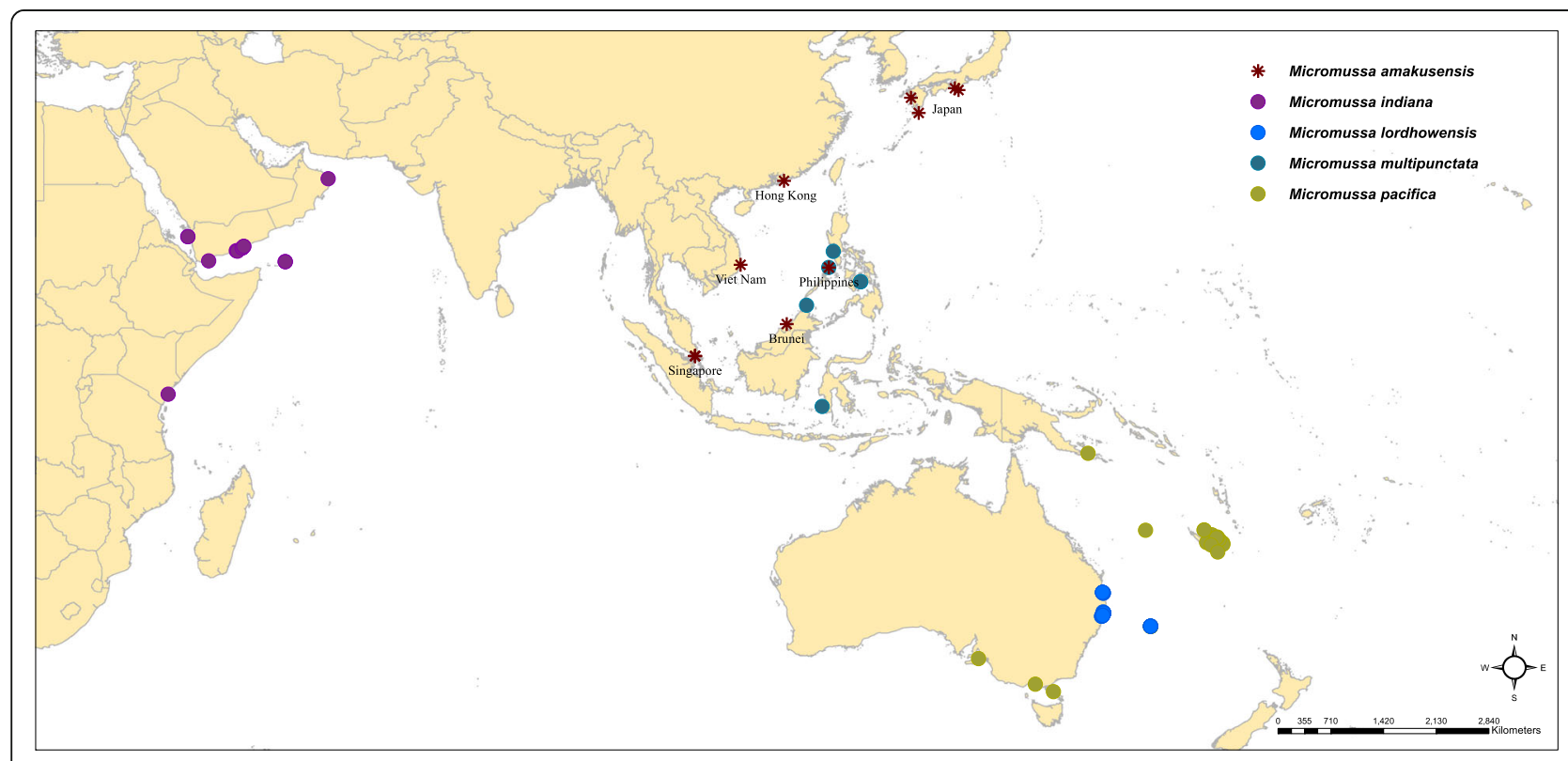

Fig. 3 Global distribution of Micromussa species according to verifiable records from Arrigoni et al. (2016a) and other published literature 
focus on M. amakusensis (Fig. 3). Our record of the species in Singapore represents a new genus and species record of M. amakusensis in the southern South China Sea. This follows a recent taxonomic revision along with two new species described that have overhauled the species ranges of existing species (Arrigoni et al. 2016a). Our phylogenetic inference is broadly congruent with the results of the revision (Arrigoni et al. 2016a; see also Arrigoni et al. 2016b, 2019; Huang et al. 2016), though it also reveals a paraphyletic $M$. amakusensis and may foreshadow further taxonomic changes.

In light of plans to develop Singapore's coastal areas in the coming decade, there is an even greater urgency to understand and manage the city-state's natural heritage (Chou et al. 2019). Increased survey efforts and taxonomic expertise, encompassing both morphological and molecular methods, will be necessary to shed light on the identities of species that have been hiding in plain sight.

\section{Methods}

SCUBA was used to access four coral reef sites at the three islands in southern Singapore from 2015 to 2019. Fragments from two colonies at Kusu Island were collected between February and March 2019 for morphological examination and molecular phylogenetic analyses. An approximately $4 \mathrm{~cm}^{2}$ piece of tissue from each colony was preserved in $100 \%$ molecular grade ethanol and stored at $-80{ }^{\circ} \mathrm{C}$ until further analysis. The remaining coral fragments were placed in freshwater for $24 \mathrm{~h}$ and $15 \%$ household bleach for one week, cleaned and dried. Specimens were examined and compared against the holotype of Micromussa amakusensis (G32485, Museum of Tropical Queensland) before depositing at the Zoological Reference Collection (ZRC.CNI.1392 and ZRC.CNI.1393), Lee Kong Chian Natural History Museum.

DNA was isolated from the ethanol-preserved subsamples using the DNeasy Blood and Tissue Kit (Qiagen) following the manufacturer's protocol. Mitochondrial cytochrome c oxidase subunit 1 (COI) gene, nuclear internal transcribed spacers (ITS) and histone H3 (HH3) were amplified using the following primers respectively: MCOIF $\left(5^{\prime}\right.$-TCT ACA AAT CAT AAA GAC ATA GG$\left.3^{\prime}\right)$ and MCOIR (5'-GAG AAA TTA TAC CAA AAC CAG G-3') (Fukami et al. 2004); A18S (5'-GAT CGA ACG GTT TAG TGA GG-3') and ITS4 $\left(5^{\prime}-\right.$ TCC TCC GCT TAT TGA TAT GC-3') (Takabayashi et al. 1998); H3F (5'-ATG GCT CGT ACC AAG CAG ACV GC-3') and H3R ( $5^{\prime}-$ ATA TCC TTR GGC ATR ATR GTG AC$3^{\prime}$ ) (Colgan et al. 1998). PCRs were performed in $25-\mu l$ reaction mixes comprising $2 \mu \mathrm{l}$ of template DNA, $12.5 \mu \mathrm{l}$ of GoTaq Green Master Mix (Promega, Wisconsin, USA), $1 \mu \mathrm{l}$ of each forward and reverse primer $(10 \mu \mathrm{M})$, and
$8.5 \mu \mathrm{l}$ of molecular grade water. The thermal cycling profile used for COI and ITS was as follows: initial denaturation at $94{ }^{\circ} \mathrm{C}$ for $1 \mathrm{~min}, 35$ cycles of $94{ }^{\circ} \mathrm{C}$ for $45 \mathrm{~s}, 48^{\circ} \mathrm{C}$ for $45 \mathrm{~s}, 72^{\circ} \mathrm{C}$ for $90 \mathrm{~s}$, and a final extension at $72^{\circ} \mathrm{C}$ for 3 min. The thermal cycling profile used for $\mathrm{HH} 3$ was as follows: initial denaturation at $95^{\circ} \mathrm{C}$ for $3 \mathrm{~min}, 40$ cycles of $95^{\circ} \mathrm{C}$ for $30 \mathrm{~s}, 53^{\circ} \mathrm{C}$ for $45 \mathrm{~s}, 72^{\circ} \mathrm{C}$ for $45 \mathrm{~s}$, and a final extension at $72^{\circ} \mathrm{C}$ for $5 \mathrm{~min}$.

Successfully amplified products were purified using SureClean Plus (Bioline Inc., London, UK), and sequenced with the BigDye Terminator v3.1 (Applied Biosystems) in a 3730xl DNA Analyzer (Thermo Fisher Scientific), following manufacturers' protocols. Gene sequences were assembled and checked using Geneious v10.1.3.

Combining data from Arrigoni et al. (2016a) and Huang et al. (2016), sequences were organised by gene in Mesquite v3.6 (Maddison and Maddison 2016), aligned using the E-INS-i option with default parameters in MAFFT v7.205 (Katoh et al. 2002; Katoh and Toh 2008; Katoh and Standley 2013), and concatenated. Maximum likelihood analysis was performed in RAxML v8.0.9 (Stamatakis 2014) with 50 alternate runs from distinct parsimony starting trees under the default GTRGAMMA model and 1000 bootstrap replicates. Bayesian analysis was carried out in MrBayes v3.2.6 (Huelsenbeck and Ronquist 2001; Ronquist and Huelsenbeck 2003; Ronquist et al. 2012) using the most suitable evolutionary model for each partition assessed via jModelTest 2.1.4 (Guindon and Gascuel 2003; Posada 2008; Darriba et al. 2012) under the Akaike information criterion. Four Markov chains of 12 million generations were implemented in two Markov chain Monte Carlo runs, saving a tree every 100th generation. The first 20,001 trees were discarded as burn-in following convergence assessment in Tracer v1.7 (Rambaut et al. 2018).

\section{Acknowledgements}

We thank Karenne Tun for discussion on coral diversity in Singapore; Roberto Arrigoni, Francesca Benzoni, Phan Kim Hoang and Vo Si Tuan for information on coral collections and records; Aden Ip and Marc Chang for assistance with imaging; and anonymous reviewers for helping to improve the manuscript.

\section{Authors' contributions}

DH, CSLN conceived the project. CSLN, YPK, SQS performed the field work. SSJ performed the laboratory work. DH, NTHN analysed the data. All authors drafted the manuscript and gave final approval for publication.

\section{Funding}

This research is supported by the National Research Foundation, Prime Minister's Office, Singapore under its Marine Science R\&D Programme (MSRDP-P03 and MSRDP-P38).

\section{Availability of data and materials}

DNA sequences are available at GenBank (accession numbers MN235859MN235860, MN249394-MN249397). 


\section{Ethics approval}

Approval to collect coral specimens was issued under the National Parks Board Singapore (research permit NP/RP16-156).

\section{Consent for publication}

Not applicable.

\section{Competing interests}

The authors declare that they have no competing interests.

Received: 30 June 2019 Accepted: 9 August 2019

Published online: 19 August 2019

\section{References}

Agapow P-M, Bininda-Emonds ORP, Crandall KA, Gittleman JL, Mace GM, Marshall JC, et al. The impact of species concept on biodiversity studies. Q Rev Biol. 2004;79(2):161-79.

Ang PO, McCorry D, Choi LS. Establishing a reference collection and field guides for Hong Kong scleractinian coral. Final report submitted to the marine conservation division, agriculture, fisheries and conservation department. Hong Kong SAR Government: Hong Kong; 2003.

Arrigoni R, Benzoni F, Huang D, Fukami H, Chen CA, Berumen ML, et al. When forms meet genes: revision of the scleractinian genera Micromussa and Homophyllia (Lobophylliidae) with a description of two new species and one new genus. Contrib Zool. 2016a:85(4):387-422.

Arrigoni R, Berumen ML, Chen CA, Terraneo TI, Baird AH, Payri C, et al. Species delimitation in the reef coral genera Echinophyllia and Oxypora (Scleractinia, Lobophylliidae) with a description of two new species. Mol Phylogenet Evol. 2016b;105:146-59.

Arrigoni R, Berumen ML, Stolarski J, Terraneo TI, Benzoni F. Uncovering hidden coral diversity: a new cryptic lobophylliid scleractinian from the Indian Ocean. Cladistics. 2019;35:301-28.

Ben-Haim Y, Zicherman-Keren M, Rosenberg E. Temperature-regulated bleaching and lysis of the coral Pocillopora damicornis by the novel pathogen Vibrio coralliilyticus. Appl Environ Microbiol. 2003;69(7):4236-42.

Benzoni F, Arrigoni R, Stefani F, Reijnen BT, Montano S, Hoeksema BW. Phylogenetic position and taxonomy of Cycloseris explanulata and C. wellsi (Scleractinia: Fungiidae): lost mushroom corals find their way home. Contrib Zool. 2012;81:125-46.

Benzoni F, Arrigoni R, Waheed Z, Stefani F, Hoeksema BW. Phylogenetic relationships and revision of the genus Blastomussa (Cnidaria: Anthozoa: Scleractinia) with description of a new species. Raffles Bull Zool. 2014;62:358-78.

Budd AF, Romano SL, Smith ND, Barbeitos MS. Rethinking the phylogeny of scleractinian corals: a review of morphological and molecular data. Integr Comp Biol. 2010;50(3):411-27.

Chan ALK, Choi CLS, McCorry D, Chan KK, Lee MW, Ang PO. Field guide to hard corals of Hong Kong. Hong Kong: Agriculture, Fisheries and Conservation Department; 2005.

Chou LM, Huang D, Tan KS, Toh TC, Goh BPL, Tun K. Singapore. In: Sheppard CRC, editor. World seas: an environmental evaluation. Volume II: The Indian Ocean to the Pacific. 2nd ed. London: Academic; 2019. p. 539-58.

Chow GSE, Chan YKS, Jain SS, Huang D. Light limitation selects for depth generalists in urbanised reef coral communities. Mar Environ Res. 2019;147:101-12.

Colgan DJ, McLauchlan A, Wilson GDF, Livingston SP, Edgecombe GD, Macaranas J, et al. Histone H3 and U2 snRNA DNA sequences and arthropod molecular evolution. Aust J Zool. 1998;46:419-37.

Cumbo VR, Fan T-Y, Edmunds PJ. Effects of exposure duration on the response of Pocillopora damicornis larvae to elevated temperature and high $\mathrm{pCO}_{2}$.J Exp Mar Biol Ecol. 2013;439:100-7.

Darriba D, Taboada GL, Doallo R, Posada D. jModelTest 2: more models, new heuristics and parallel computing. Nat Methods. 2012;9(8):772.

Ely CV, de Loreto Bordignon SA, Trevisan R, Boldrini II. Implications of poor taxonomy in conservation. J Nat Conserv. 2017;36:10-3.

Fukami H, Budd AF, Paulay G, Solé-Cava A, Chen CA, Iwao K, et al. Conventional taxonomy obscures deep divergence between Pacific and Atlantic corals. Nature. 2004;427(6977):832-5.

Fukami H, Chen CA, Budd AF, Collins A, Wallace C, Chuang Y-Y, et al. Mitochondrial and nuclear genes suggest that stony corals are monophyletic but most families of stony corals are not (order Scleractinia, class Anthozoa, phylum Cnidaria). PLoS One. 2008;3(9):e3222.

Gittenberger A, Reijnen BT, Hoeksema BW. A molecularly based phylogeny reconstruction of mushroom corals (Scleractinia: Fungiidae) with taxonomic consequences and evolutionary implications for life history traits. Contrib Zool. 2011;80(2):107-32.

Guest JR, Tun K, Low J, Vergés A, Marzinelli EM, Campbell AH, et al. 27 years of benthic and coral community dynamics on turbid, highly urbanised reefs off Singapore. Sci Rep. 2016;6:36260.

Guindon S, Gascuel O. A simple, fast, and accurate algorithm to estimate large phylogenies by maximum likelihood. Syst Biol Oxford University Press. 2003; 52(5):696-704.

Hodgson G. A new species of Montastrea (Cnidaria, Scleractinia) from the Philippines. Pac Sci. 1985;39(3):283-90.

Hoeksema BW. Delineation of the indo-Malayan Centre of maximum marine biodiversity: the coral triangle. In: Renema W, editor. Biogeography, time, and place: distributions, barriers, and islands. Dordrecht: Springer Netherlands; 2007. p. 117-78.

Hoeksema BW, Koh EGL. Depauperation of the mushroom coral fauna (Fungiidae) of Singapore (1860s-2006) in changing reef conditions. Raffles Bull Zool. 2009;:S22:91-101.

Huang D, Arrigoni R, Benzoni F, Fukami H, Knowlton N, Smith ND, et al. Taxonomic classification of the reef coral family Lobophylliidae (Cnidaria: Anthozoa: Scleractinia). Zool J Linnean Soc. 2016;178(3):436-81.

Huang D, Licuanan WY, Hoeksema BW, Chen CA, Ang PO, Huang H, et al. Extraordinary diversity of reef corals in the South China Sea. Mar Biodivers. 2015;45(2):157-68.

Huang D, Tun KPP, Chou LM, Todd PA. An inventory of zooxanthellate scleractinian corals in Singapore, including 33 new records. Raffles Bull Zool. 2009:S22:69-80.

Huelsenbeck JP, Ronquist F. MRBAYES: Bayesian inference of phylogenetic trees. Bioinformatics. 2001;17(8):754-5

Hughes TP, Barnes ML, Bellwood DR, Cinner JE, Cumming GS, Jackson JBC, et al. Coral reefs in the Anthropocene. Nature. 2017;546:82-90.

Hughes TP, Bellwood DR, Connolly SR, Cornell HV, Karlson RH. Double jeopardy and global extinction risk in corals and reef fishes. Curr Biol. 2014;24:2946-51.

Johnston EC, Forsman ZH, Toonen RJ. A simple molecular technique for distinguishing species reveals frequent misidentification of Hawaiian corals in the genus Pocillopora. PeerJ. 2018;6(10):e4355.

Katoh K, Misawa K, Kuma K-I, Miyata T. MAFFT: a novel method for rapid multiple sequence alignment based on fast Fourier transform. Nucleic Acids Res. 2002 30(14):3059-66.

Katoh K, Standley DM. MAFFT multiple sequence alignment software version 7: improvements in performance and usability. Mol Biol Evol. 2013;30(4):772-80.

Katoh $\mathrm{K}$, Toh H. Recent developments in the MAFFT multiple sequence alignment program. Brief Bioinform. 2008;9(4):286-98.

Keshavmurthy S, Yang S-Y, Alamaru A, Chuang Y-Y, Pichon M, Obura D, et al. DNA barcoding reveals the coral "laboratory-rat," Stylophora pistillata encompasses multiple identities. Sci Rep. 2013;3:1520.

Kitahara MV, Fukami H, Benzoni F, Huang D. The new systematics of Scleractinia: integrating molecular and morphological evidence. In: Goffredo S, Dubinsky Z, editors. The Cnidaria, past, present and future. Cham: Springer International Publishing; 2016. p. 41-59.

Kitano YF, Nagai S, Ueno M, Yasuda N. Most Pocillopora damicornis around Yaeyama Islands are Pocillopora acuta according to mitochondrial ORF sequences. Galaxea. 2015;17(1):21-2.

Lee AC, Tan KS, Sin TM. Intertidal assemblages on coastal defence structures in Singapore I: a faunal study. Raffles Bull Zool. 2009;522:237-54.

Mace GM. The role of taxonomy in species conservation. Philos Trans $\mathrm{R}$ Soc Lond B-Biol Sci. 2004;359(1444):711-9.

Maddison WP, Maddison DR. Mesquite: a modular system for evolutionary analysis. 2016. Available from: http://mesquiteproject.org

Madin JS, Anderson KD, Andreasen MH, Bridge TCL, Cairns SD, Connolly SR, et al. The coral trait database, a curated database of trait information for coral species from the global oceans. Sci Data. 2016;3:160017.

Mayfield AB, Bruckner AW, Chen C-H, Chen C-S. A survey of pocilloporid corals and their endosymbiotic dinoflagellate communities in the austral and Cook Islands of the South Pacific. Platax. 2015;12:1-17.

Montgomery AD, Fenner D, Toonen RJ. Annotated checklist for stony corals of American Sămoa with reference to mesophotic depth records. ZooKeys. 2019;849:1-170. 
Ng CSL, Chen D, Chou LM. Hard coral assemblages on seawalls in Singapore. In Tan KS, editor. Contributions to marine science. Singapore: National University of Singapore; 2012. p. 75-9.

Obura D. An Indian Ocean Centre of origin revisited: Palaeogene and Neogene influences defining a biogeographic realm. J Biogeogr. 2016;43:229-42.

Pandolfi JM, Bradbury RH, Sala E, Hughes TP, Bjorndal KA, Cooke RG, et al. Global trajectories of the long-term decline of coral reef ecosystems. Science. 2003;301:955-8.

Poquita-Du RC, Huang D, Chou LM, Mrinalini TPA. Short term exposure to heat and sediment triggers changes in coral gene expression and photophysiological performance. Front Mar Sci. 2019a;6:121.

Poquita-Du RC, Ng CSL, Loo JB, Afiq-Rosli L, Tay YC, Todd PA, et al. New evidence shows that Pocillopora "damicornis-like" corals in Singapore are actually Pocillopora acuta (Scleractinia: Pocilloporidae). Biodivers Data J. 2017;5:e11407.

Poquita-Du RC, Quek ZBR, Jain SS, Schmidt-Roach S, Tun K, Heery EC, et al. Last species standing: loss of Pocilloporidae corals associated with coastal urbanization in a tropical city state. Mar Biodivers. 2019b;49(4):1727-41.

Posada D. jModelTest: Phylogenetic model averaging. Mol Biol Evol. 2008; 25(7):1253-6.

Rambaut A, Drummond AJ, Xie D, Baele G, Suchard MA. Posterior summarisation in Bayesian phylogenetics using tracer 1.7. Syst Biol. 2018;67(5):901-4.

Ronquist F, Huelsenbeck JP. MrBayes 3: Bayesian phylogenetic inference under mixed models. Bioinformatics; Oxford University Press. 2003;19(12):1572-4.

Ronquist F, Teslenko M, van der Mark P, Ayres DL, Darling A, Höhna S, et al. MrBayes 3.2: efficient Bayesian phylogenetic inference and model choice across a large model space. Syst Biol. 2012;61(3):539-42.

Schmidt-Roach S, Miller KJ, Lundgren P, Andreakis N. With eyes wide open: a revision of species within and closely related to the Pocillopora damicornis species complex (Scleractinia; Pocilloporidae) using morphology and genetics. Zool J Linnean Soc. 2014;170(1):1-33.

Stamatakis A. RAxML version 8: a tool for phylogenetic analysis and post-analysis of large phylogenies. Bioinformatics. 2014;30(9):1312-3.

Stefani F, Benzoni F, Yang S-Y, Pichon M, Galli P, Chen CA. Comparison of morphological and genetic analyses reveals cryptic divergence and morphological plasticity in Stylophora (Cnidaria, Scleractinia). Coral Reefs. 2011;30:1033-49.

Takabayashi M, Carter DA, Ward S, Hoegh-Guldberg O. Inter- and intra-specific variability in ribosomal DNA sequence in the internal transcribed spacer region of corals. In: Proceedings of the Australian Coral Reef Society 75th Anniversary Conference, Heron Island, October 1997. Brisbane: School of Marine Science, University of Queensland; 1998. p. 241-8.

Torres AF, Ravago-Gotanco R. Rarity of the "common" coral Pocillopora damicornis in the western Philippine archipelago. Coral Reefs. 2018;37(4):1209-16.

Turak E, DeVantier L. Corals and coral communities. In: Investigating catchment runoff to aquatic environments (freshwater, estuarine, marine) in the Milne Bay area and development of a best management guide for oil palm development to protect aquatic environments; 2007. http://mww.researchgate.net/publication/285471341_Turak _and_DeVantier_2007_Investigating_catchment_runoff_to_aquatic_environments _freshwater_estuarine_marine_in_the_Milne_Bay_area_and_development_of_a_best _management_guide_for_oil_palm_development_to. Accessed 27 May 2019.

Turak E, DeVantier LM. Field guide to reef-building corals of Brunei Darussalam. Bandar Seri Begawan: Fisheries Department, Ministry of Industry and Primary Resources; 2011.

Veron JEN. New Scleractinia from Japan and other Indo-West Pacific countries. Galaxea. 1990;9:95-173.

Veron JEN. Corals in space and time. Sydney: UNSW Press; 1995.

Veron JEN. Corals of the world. Townsville: Australian Institute of Marine Science; 2000.

Veron JEN. New species described in Corals of the world. Townsville: Australian Institute of Marine Science; 2002.

Veron JEN, Pichon M. Scleractinia of eastern Australia. Part I. families Thamnasteriidae, Astrocoeniidae, Pocilloporidae. Townsville: Australian Institute of Marine Science; 1976.

Veron JEN, Pichon M. Scleractinia of eastern Australia. Part III. Families Agariciidae, Siderastreidae, Fungiidae, Oculinidae, Merulinidae, Mussidae, Pectiniidae, Caryophylliidae, Dendrophylliidae. Townsville: Australian Institute of Marine Science; 1980.

Veron JEN, Stafford-Smith MG, Turak E, DeVantier LM. Micromussa amakusensis (Veron, 1990). In: Corals of the world. Coral Reef Research; 2016. http://www. coralsoftheworld.org/species_factsheets/species_factsheet_summary/ micromussa-amakusensis. Accessed 14 May 2019.
Vo ST, DeVantier LM, Nguyen VL, Tuyen HT, Nguyen XH, Hoàng PK. Coral reefs of Hon Mun Marine Protected Area, Nha Trang Bay, Vietnam, 2002: species composition, community structure, status and management recommendations. In: Proceedings of the Scientific Conference "Bien Dong 2002". Nha Trang: Agricultural Publishing House; 2002. p. 653-94.

Wallace CC, Fellegara I, Muir PR, Harrison PL. The scleractinian corals of Moreton Bay, eastern Australia: high latitude, marginal assemblages with increasing species richness. Mem Qld Mus. 2009;54(2):1-118.

Wong JSY, Chan YKS, Ng CSL, Tun KPP, Darling ES, Huang D. Comparing patterns of taxonomic, functional and phylogenetic diversity in reef coral communities. Coral Reefs. 2018;37(3):737-50.

\section{Publisher's Note}

Springer Nature remains neutral with regard to jurisdictional claims in published maps and institutional affiliations.
Ready to submit your research? Choose BMC and benefit from:

- fast, convenient online submission

- thorough peer review by experienced researchers in your field

- rapid publication on acceptance

- support for research data, including large and complex data types

- gold Open Access which fosters wider collaboration and increased citations

- maximum visibility for your research: over $100 \mathrm{M}$ website views per year

At BMC, research is always in progress.

Learn more biomedcentral.com/submissions 